Vol. 3 No. 4 Desember $2016: 9$ - 18

\title{
KEDUDUKAN HUKUM DAN HAK PENJAMIN TERHADAP JAMINAN KREDIT ATAS PENYELESAIAN KREDIT YANG DILAKUKAN OLEH PENJAMIN TERHADAP DEBITUR YANG WANPRESTASI (STUDI KASUS PUTUSAN NOMOR 05/Pdt.G/2016/PN.PWT)
}

\author{
Budi Primalia Aldanita*)
}

*) Mahasiswa Program Magister Kenotariatan UNISSULA,email : $\underline{\text { Primaliabudi@ yahoo.co.id }}$

\begin{abstract}
ABSTRAK
Perjanjian kredit merupakan perjanjian yang melibatkan debitur dan kreditur, dan terkadang melibatkan pihak ketiga sebagai penjamin kredit. Pihak kreditur tentu berharap pihak debitur dapat memenuhi prestasinya dengan membayar angsuran kredit tepat waktu. Prakteknya, tidak semua debitur dapat memenuhi prestasinya baik disengaja atau tidak, bahkan memenuhi unsur wanprestasi seperti pada kasus Putusan Nomor 05/Pdt.G/2016/PN.PWT yang dikaji dalam tesis ini.

Tujuan penelitian ini adalah untuk menganalisis: 1) Kedudukan hukum dan hak penjamin terhadap jaminan kredit atas penyelesaian kredit yang dilakukan oleh Debitur yang wanprestasi dalam Putusan Nomor 05/Pdt.G/2016/PN.PWT, 2) Kendala dan solusi atas penyelesaian kredit yang dilakukan oleh penjamin terhadap debitur yang wanprestasi dalam Putusan Nomor 05/Pdt.G/2016/PN.PWT, dan 3) Akibat hukum atau perlindungan hukum penjamin dalam Putusan Nomor 05/Pdt.G/2016/PN.PWT.Penelitian ini merupakan penelitian deskriptif dengan pendekatan hukum normatif. Data yang digunakan adalah data sekunder dan data tersier sebagai data penunjang, yang kemudian dianalisis dengan metode deskriptif-kualitatif.

Berdasarkan hasil penelitian yang diperoleh disimpulkan bahwa 1) Kedudukan hukum Penjamin dalam perkara Nomor 05/Pdt.G/2016/PN.PWT adalah sebagai debitur yang berkewajiban untuk membayar kredit debitur, 2) Kendala dalam Putusan Nomor 05/Pdt.G/2016/PN.PWT adalah pihak debitur tidak beritikad baik, dan solusinya adalah melalui jalur hukum dan sudah tepat, karena memiliki kekuatan hukum yang sah dan mengikat semua pihak, 3) Akibat hukum atas Putusan Nomor 05/Pdt.G/2016/PN.PWT. adalah ditetapkannya penilaian wanprestasi kepada Andy Syah Putra selaku debitur dan mengakibatkan Yohanes Sucipto Dadi menjadi debitur dan memenuhi kewajibannya membayar semua hutang Andy Syah Putra. Perlindungan hukum bagi Penjamin atas Putusan Nomor 05/Pdt.G/2016/PN.PWT. adalah keputusan Majelis Hakim Pengadilan Negeri Purwokerto dengan mengabulkan gugatan Penjamin.
\end{abstract}

Kata Kunci: Kedudukan hukum, Hak, Penjamin, Penyelesaian kredit,Debitur wanprestas

\section{PENDAHULUAN}

Perjanjian kredit merupakan perjanjian yang melibatkan debitur dan kreditur, dan terkadang melibatkan pihak ketiga sebagai penjamin kredit. Pihak kreditur tentu berharap pihak debitur dapat memenuhi prestasinya dengan membayar angsuran kredit tepat waktu. Prakteknya, tidak semua debitur dapat memenuhi prestasinya baik disengaja atau tidak, bahkan memenuhi unsur wanprestasi seperti pada kasus Putusan Nomor 05/Pdt.G/2016/PN.PWT Berdasarkan uraian 
di atas maka penulis tertarik untuk mengkaji permasalahan hukum di atas dengan melakukan penelitian yang berjudul: "Kedudukan Hukum dan Hak Penjamin terhadap Jaminan Kredit Atas Penyelesaian Kredit yang Dilakukan Oleh Penjamin Terhadap Debitur yang Wanprestasi Studi Kasus Putusan Nomor 05/Pdt.G/2016/PN.PWT”.

Berdasarkan uraian tersebut diatas, maka dapat dirumuskan permasalahan sebagai berikut:

1. Bagaimana kedudukan hukum dan hak Penjamin terhadap jaminan kredit atas penyelesaian kredit yang dilakukan oleh Penjamin terhadap Debitur yang wanprestasi dalam perkara Nomor 05/Pdt.G/2016/PN.PWT?

2. Apa kendala dan solusi atas penyelesaian kredit yang dilakukan oleh Penjamin terhadap Debitur yang wanprestasi dalam perkara Nomor 05/Pdt.G/2016/PN.PWT?

3. Apa akibat hukum atau perlindungan hukum Penjamin terhadap perkara Nomor 05/Pdt.G/2016/PN.PWT

\section{PEMBAHASAN}

\section{Kedudukan Hukum dan Hak Penjamin Terhadap Jaminan Kredit atas Penyelesaian Kredit yang Dilakukan oleh Penjamin Terhadap Debitur yang Wanprestasi dalam Perkara Nomor 05/Pdt.G/2016/PN.PWT}

Hak istimewa yang dimiliki seorang penjamin ini tercantum dalam pasal $1831 \mathrm{KUH}$ Perdata. Hak istimewa tersebut dipertegas pada Pasal 1834 KUHPerdata yaitu pihak penjamin dapat menuntut supaya harta benda debitur lebih dahulu disita dan dilelang, dan membayar lebih dahulu biaya yang diperlukan untuk melaksakan penyitaan serta pelelangan tersebut. Hak istimewa yang dimiliki seorang Penjamin itu ada karena Penjamin (Borgtocht) sifatnya hanya sebagai cadangan saja, artinya jika debitur tidak melunasi hutangnya maka penjamin melunasi hutang 
Vol. 3 No. 4 Desember $2016: 9$ - 15

debitur. Hak istimewa tersebut biasanya dalam praktek membuat perjanjian jaminan dihapuskan atau ditiadakan.

Akibat dihapuskannya hak-hak istimewa tersebut maka kedudukan seorang Penjamin adalah seperti si berhutang sendiri artinya apabila si berhutang (debitur) tidak membayar hutangnya maka si Penjamin bisa ditagih untuk segera melunasi hutang debitur. Penjamin ikut memikul segala akibat hukum yang menimbulkan kerugian moril maupun materiil, jika timbul suatu keadaan yang menimpa obyek yang dimaksudkan dalam perjanjian. Hal ini seperti yang terjadi dalam perkara Putusan Nomor 05/Pdt.G/2016/PN.PWT

\section{Kendala dan Solusi atas Penyelesaian Kredit yang dilakukan oleh Penjamin terhadap Debitur yang Wanprestasi dalam Perkara Nomor 05/Pdt.G/2016/PN.PWT.}

Kendala dalam penyelesaian permasalahan antara lain adalah:

1) Pihak debitur yaitu Andy Syah Putra melarikan diri dari tanggung jawabnya dan tidak dapat dihubungi oleh pihak Bank BTN Cabang Purwokerto untuk memenuhi prestasinya.

2) Pihak Yohanes Sucipto Dadi selaku Penjamin tidak dapat menghubungi Andy Syah Putra untuk dimintai pertanggungjawabannya atas kredit yang menggunakan harta bendanya sebagai jaminan kredit di bank BTN Cabang Purwokerto.

3) Andy Syah Putra tidak pernah menghadiri persidangan selama proses persidangan hingga diputuskannya perkara di Pengadilan Negeri Purwokerto.

Upaya yang dilakukan untuk mengatasi dan menyelesaikan permasalahan di atas adalah diselesaikan dengan bantuan hukum,

Solusi yang diupayakan untuk masalah tersebut oleh Pengadilan Negeri Purwokerto adalah: ${ }^{1}$

\footnotetext{
${ }^{1}$ Salinan Putusan Nomor 05/Pdt.G/2016/PN.PWT. hal.12.
} 
Pertama, Upaya perdamaian antara Penjamin dan Debitur serta Kreditur pada sidang pertama. Kedua. Melanjutkan proses pengadilan ke tahap selanjutnya karena upaya perdamaian tidak berhasil dilakukan, yaitu tahap pemeriksaan atas bukti-bukti yang diajukan Penjamin dikuatkan dengan saksi-saksi untuk mendapatkan penilaian yuridis dari majelis hakim, yang kemudian dilanjutkan sampai dengan ditetapkannya putusan atas pokok perkara jaminan kredit di Bank BTN Cabang Purwokerto milik Penjamin atas kredit debitur yang melakukan wanprestasi. Ketiga. Pihak Penjamin membayar kewajiban debitur kepada kreditur untuk memenuhi prestasi debitur dan mengamankan barang jaminan milik Penjamin. Keempat. Ditetapkannya putusan Pengadilan Negeri Purwokerto yang bersifal final dan mengikat semua pihak yang berperkara dalam Putusan Nomor 05/Pdt.G/2016/PN.PWT. serta berkekuatan hukum yang sah.

\section{Akibat Hukum atau Perlindungan Hukum Penjamin terhadap perkara Nomor 05/Pdt.G/2016/PN.PWT}

Akibat hukum yang dilakukan oleh Andy Syah Putra yang tidak berprestasi sama sekali karena sejak berlakunya perjanjian kredit sampai dengan empat bulan ke depan tidak mengangsur hutangnya ke Bank BTN Cabang Purwokerto. Tindakannya tersebut membawa akibat hukum yaitu dinyatakan wanprestasi oleh Majelis Hakim

Pengadilan Negeri Purwokerto dalam putusan perkara No.05/Pdt.G/2016/PN.PWT. Pernyataan wanprestasi tersebut membuat debitur harus menanggung segala akibat yang merugikan kreditur karena diakibatkan tidak dipenuhinya prestasi. Ingkar janji (wanprestasi) yang dilakukan oleh Andy Syah Putra tidak hanya menimbulkan kerugian bagi pihak Bank BTN Cabang Purwokerto saja selaku kreditur tetapi juga mengakibatkan kerugian pada Yohanes

Sucipto Dadi selaku Penjamin kredit tersebut. Ingkar janji dalam perjanjian kredit sangat banyak penyebabnya seperti kesulitan keuangan yang dialami oleh debitur atau bahkan tidak ada itikad baik dari debitur untuk memenuhi prestasinya di mana hal ini terkait dengan karakter dari debitur, 
Vol. 3 No. 4 Desember $2016: 9$ - 15

di mana hal inilah yang menjadi penyebab wanprestasi pada kasus perkara yang dikaji iniPerlindungan hukum bagi Penjamin dalam perkara Nomor 05/Pdt.G/2016/PN.PWT. diperoleh Penjamin yaitu dalam keputusan Majelis Hakim Pengadilan Negeri Purwokerto dengan cara menegakkan peraturan yaitu mengabulkan gugatan Penjamin terkait pernyataan wanprestasi bagi debitur dan penyerahan sertifikai tanah dan bangunan hak milik atas nama Penjamin. Hal ini berarti perlindungan hukum bagi Penjamin baru terjadi setelah Penjamin menempuh jalur hukum untuk memperjuangkan harta bendanya yang dijadikan jaminan oleh debitur yang wanprestasi.

\section{PENUTUP}

\section{Kesimpulan}

Berdasarkan hasil analisis yang diperoleh dalam penelitian ini, dapat diambil kesimpulan sebagai berikut:

1. Kedudukan hukum Penjamin atas penyelesaian kredit yang dilakukan oleh Debitur yang wanprestasi dalam perkara Nomor 05/Pdt.G/2016/PN.PWT karena debitur tidak dapat membayar hutangnya maka Penjamin berkedudukan sebagai debitur yang berkewajiban untuk membayar bahkan melunasi kredit debitur. Penjamin berhak untuk tidak menjual jaminan kredit terlebih dulu sebelum debitur menjual hartanya untuk melunasi kreditnya, namun pada perkara jaminan atas penyelesaian kredit yang dilakukan oleh Debitur yang wanprestasi dalam perkara Nomor 05/Pdt.G/2016/PN.PWT, Penjamin tidak memiliki hak tersebut karena debitur tidak bertanggungjawab.

2. Kendala dalam penyelesaian kredit yang dilakukan oleh Penjamin terhadap Debitur yang wanprestasi dalam perkara Nomor 05/Pdt.G/2016/PN.PWT adalah pihak debitur tidak beritikad baik dengan tidak menghadiri semua persidangan di pengadilan negeri Purwokerto sampai dengan putusan perkara dibacakan dan ditetapkan. Solusi yang ditempuh atas 
penyelesaian kredit tersebut melalui jalur Hukum adalah solusi yang tepat, karena memiliki kekuatan hukum yang sah dan mengikat semua pihak yang berperkara.

3. Akibat hukum atas perkara Nomor 05/Pdt.G/2016/PN.PWT. adalah ditetapkannya penilaian wanprestasi kepada Andy Syah Putra selaku debitur Bank BTN Cabang Purwokerto, yang mengakibatkan Yohanes Sucipto Dadi menjadi debitur dan memenuhi kewajibannya membayar semua hutang Andy Syah Putra. Pada prinsipnya perbuatan yang dilakukan oleh Andy Syah Putra tersebut secara materiil telah merugikan pihak Penjamin yaitu Yohanes Sucipto Dadi. Perlindungan hukum bagi Penjamin atas perkara Nomor 05/Pdt.G/2016/PN.PWT. adalah keputusan Majelis Hakim Pengadilan Negeri Purwokerto yang memberi perlindungan hukum dengan cara menegakkan peraturan yaitu mengabulkan gugatan Penjamin terkait pernyataan wanprestasi bagi debitur dan penyerahan sertifikai tanah dan bangunan hak milik atas nama Penjamin. Hal ini berarti perlindungan hukum bagi Penjamin atas perkara Nomor 05/Pdt.G/2016/PN.PWT

\section{DAFTAR PUSTAKA}

Abdulkadir Muhammad, 2000. Hukum Perdata Indonesia, Bandung,: Citra Aditya Bhakti.

A Qirom Syamsuddin M, 1985. Pokok-Pokok Hukum Perjanjian Beserta Perkembangannya, Yogyakarta: Liberty.

Ahmad Al-Mursi Husain Jauhar. 2009. Maqoshid Syariah. Jakarta: Amzah.

Ahmadi Miru, 2010, Hukum Kontrak dan Perancangan Kontrak, Cet. Ke- 3, Jakarta: Rajawali Pers. Arief Masdoeki, M.H. Tirtamidjaja, 1963, Asas dan Dasar Hukum Perdata, Jakarta: Djambatan.

C.s.t. Kansil, 2006. Modul Hukum Perdata Termasuk Asas-Asas Hukum Perdata, ,Jakarta: Pradnya Paramita.

Elly Erawati dan Herlien Budiono, 2001. Penjelasan Hukum tentang Kebatalan Perjanjian, Bandung: Alumni.

Gunawan Widjaja, 2003. Hapusnya Perikatan, Jakarta: Grafindo Persada.

Guntoro, Heru. 2009. Tanggung Gugat Pihak Penjamin dalam Perjanjian Kredit Akibat Wanprestasi. Jurnal Ilmiah Progressif Vol.6.No.15. 8-18.

Hariyani, Iswi \& Serfianto, R. 2010. Bebas Jeratan Utang Piutang, Yogyakarta: Pustaka Yustisia. H.Halim, HS. 2001. Perkembangan Hukum Jaminan di Indonesia. Jakarta: PT. Rajawali Pers. 
Vol. 3 No. 4 Desember 2016 : 9 - 15

Herlien Budiono, 2011. Ajaran Umum Hukum Perjanjian dan Penerapannya di Bidan kenotariatan. Bandung: PT. Citra Aditia Bakti.

I Ketut Artadi dan I Dw. Nym. Rai Asmara P., 2010, Implementasi Ketentuan-Ketentuan Hukum

Perjanjian kedalam Perancangan Kontrak, Denpasar:. Udayan University Press.

J. Satrio, 1992. Hukum Perjanjian (Perjanjian Pada Umumnya). Jakarta: PT.Citra Aditya Bakti. 1995. Hukum Perikatan yang Lahir dari Perjanjian Buku I, Bandung: Citra Aditya Bhakti.

Kartini Muljadi dan Gunawan Widjaja, 2003. Perikatan Pada Umumnya, Jakarta: Raja Grafindo Persada.

Lukman Santoso Az, 2012, Hukum Perjanjian Kontrak, Yogyakarta: Cakrawala.

Mariam Darus Baruldzaman. 1991. Bab-bab tentang Credit Verband, Gadai dan Fiducia. Bandung: Citra Aditya Bakti. 1993. Perjanjian Kredit Bank, Bandung: Alumni.

(1) 2001. Kompilasi Hukum Perikatan, Bandung,: Citra Aditya Bhakti.

Munir Fuady, 2001. Hukum Kontrak (Dari Sudut Pandang Hukum Bisnis), Bandung: Citra Aditya Bakti.

Peter Mahmud Marzuki. 2010. Penelitian Hukum. Jakarta :Kencana Persada.

Paul Scholten di dalam JJ. H Bruggink,1996. Refleksi Tentang Hukum, (alih bahasa oleh Arief Sidharta) . Bandung: Cipta Aditya Bhakti.

Pius A Partono dan M Dahlan, 1994. Al-Berr, Kamus Ilmiah Favorit, , Surabaya: Anka.

Purwahid Patrik, 1962. Asas Itikad Baik dan Kepatutan dalam Perjanjian, Semarang: Fakultas Hukum Universitas Diponegoro.

Rooseno Harjowidigji, 1993. Presfektif Peraturan Franchise, Jakarta: BPHN.

Satijipto Raharjo. 2000. Ilmu Hukum. Bandung: PT. Citra Aditya Bhakti.

Sri Sumantri, 1971. Perbandingan Antar Hukum Tata Negara. Bandung: Alumni. 